\author{
Józef P. Girjatowicz \\ University of Szczecin \\ Hydrography and Water Management Unit \\ girjatjp@univ.szczecin.pl
}

\title{
TOURISTICALLY-ATTRACTIVE SPRINGS IN THE POLISH LOWLANDS
}

\begin{abstract}
On the basis of available published materials and his own research, the author identifies the 27 most attractive springs in the Polish Lowlands. He describes their most important landscape and tourism assets - the relief of the spring outlet area, landforms, the character of the spring itself and the accompanying tourism infrastructure. The article presents available data regarding the water discharged by the springs: volume, temperature, colour and medicinal properties; as well as pointing to associated interesting natural features, examples of religious architecture and historical curiosities. The distribution of springs in the Polish Lowlands is uneven, with the majority found in the area of the morainic uplands, as well as in deeper river valleys and lake troughs.
\end{abstract}

Key words: springs, landscape and tourism assets, Polish Lowlands.

A spring is the site of a natural discharge of groundwater to the surface of the earth from a single source, through an opening, crack or fracture. It occurs at places where the surface of the earth cuts an aquifer.

There are various criteria for classifying springs, the main one being the nature of the underlying rock (e.g. porous, jointed, with caves). Using this particular one, springs can be divided into "layer", fracture, fault and karst. In mountains and uplands, fracture, fault and karst springs emerging mostly from solid rock are found. In the lowlands, they are predominantly 'layer' springs, draining water from a 'layer' in a porous formation e.g. sands or gravels. Taking into consideration the force causing the discharge, they are descending (gravity) springs in which the water is flowing downwards. They are a part of a post-glacial landscape, especially in higher areas with varied relief. There are many in districts of lakes, especially in post-glacial troughs. Spring discharge in lowlands, however, is small, usually less than $0.5 \mathrm{l} / \mathrm{s}$ (litres per second), although in some cases it reaches several dozen litres per second.

Some springs in Poland are considered to be sacred and sites of religious cults. They are often named after saints or sanctuaries, and are believed to have miraculous (healing) powers. That is why we find shrines, churches, sanctuaries etc. built near them, often visited by pilgrims and tourists.

Moreover, springs not only have interesting hydrological features, but are also a part of the landscape, and as such they become attractive to tourists, in addition to displaying healing and other features.
Detailed information about the Polish Lowlands can be found in numerous specialist publications, mainly in articles published in academic journals (DYNOWSKA 1986, MAKSYMIUK \& MELA 1995, POLESZCZUK 1998, MONIEWSKI 2004), and conference proceedings (FORYSIAK \& MONIEWSKI 2006, MONIEWSKI et al. 2006, BAŚCIK \& URBAN 2007, JOKIEL et al. 2007). Mentions of the tourism value of springs are included in guidebooks (ALEXANDROWICZ et al. 1975, MARCINEK \& CHRUŚCICKI 1976, PASIECZNY et al. 2008), as well as geographical and tourism gazetteers and encyclopaedias (MILEWSKA 1998, KWIATEK \& LIJEWSKI 1993, ŁĘCKI 2005, KRYGIER 2007). Information on the tourism value of springs can be found in tourism geography textbooks (CHOIŃSKI \& KANIECKI 1996, MAIK 2000, LIJEWSKI et al. 2008), and monographs (OLACZEK 2008, GEĄBIŃSKI 2009, DOMIAN \& KUPIEC 2010). Sometimes springs are also mentioned in general geography textbooks (STARKEL 1999, KONDRACKI 1998, CHEEMICKI et al. 2010). General information about springs is found in hydrography and hydrology textbooks (MIKULSKI 1965, DYNOWSKA \& TLAŁKA 1982, BAJKIEWICZ-GRABOWSKA \& MIKULSKI 2006), as well as in books with religious themes (JACKOWSKI 1998, WIŚNIEWSKI 1998, ŻELAWSKI 2010).

The aim of this article is to present the natural and human assets of springs in the Polish Lowlands on the basis of the available literature, internet sources, and the author's own field work. The information may encourage tourists to visit these springs.

On the basis of available published materials and his own research, the author has listed 27 springs 


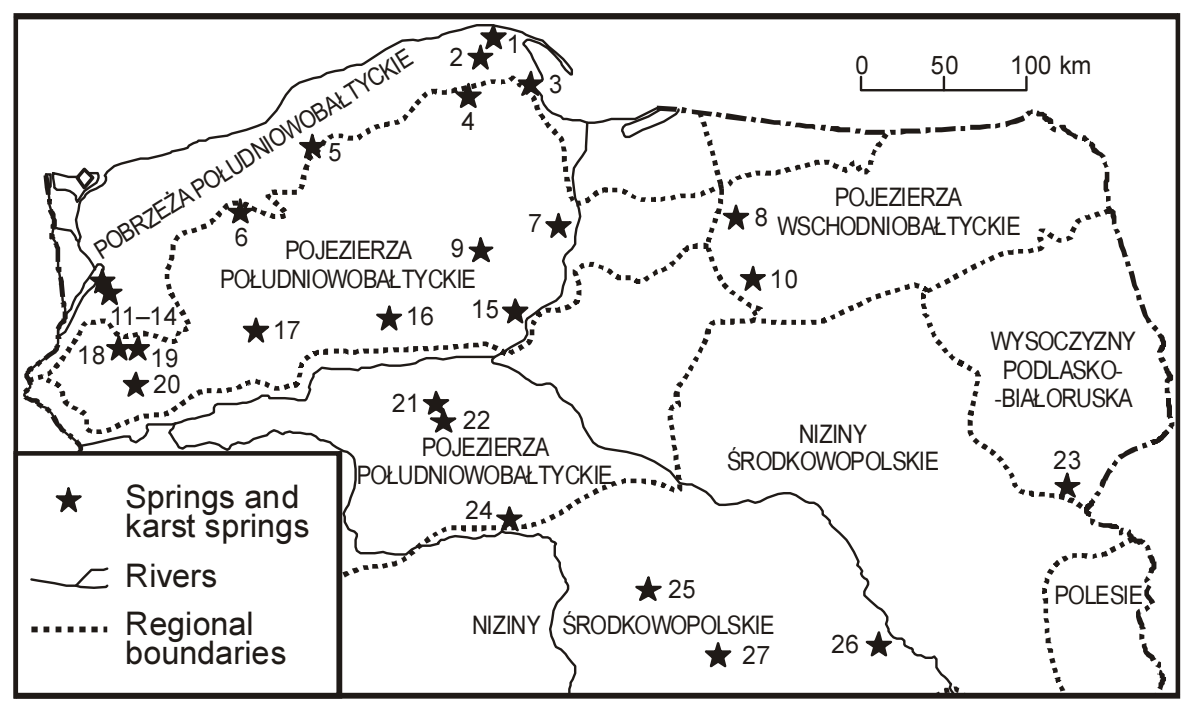

Fig. 1. Distribution of touristically-attractive springs in the Polish Lowlands Sou r c e: author

showing tourism value. Their spatial distribution in the Polish Lowlands is presented in Fig. 1. The author chose those springs whose natural and human assets are described in the literature or on the internet, and/or are visited by large numbers of pilgrims and tourists travelling to religious sites. The description includes the names of these springs, their exact locations plus nearby places, position in a named valley (along with the stream or river name), and the geographical region, as well as information about the relief of the water discharge area (valley side and foot, fracture, outlet). Further information concerns the character of the area surrounding the spring, the type of rock from which the water flows, as well as its colour, volume and temperature. The accompanying tourism infrastructure, interesting natural features, religious sites, the medicinal properties of the water and historical remarks are also mentioned. The name of the landscape park or/and nature reserve and the name of a tourism trail leading to it are included as well. The landscape and human assets of selected springs are presented in photographs (Fots 2-6).

Brief descriptions of touristically-attractive springs are presented below, starting from the north and ending with those located in the south of the Polish Lowlands.

1. Małe Źródetko (Little Spring), called 'Zdróik' by the local people (Kashubians), is a natural spring with medicinal properties emerging from the foot of a slope in the north-western part of Kępa Ostrowska, about $0.5 \mathrm{~km}$ west of the village of Ostrowo. It is situated near the Karwieńska road from Ostrów to Karwia which runs through meadows (Władysławowo gmina, Puck powiat). The spring is surrounded by a low concrete wall and its water was formerly used for agriculture. There are several boulders, about $1 \mathrm{~m}$ in diameter, surrounding the spring. The path leading to it has a hard surface and you can find a small bench and a table there. Through a series of ditches, the spring feeds the river, Czarna Woda, which flows directly into the sea. Slightly to the south is the 'Bielawskie Marshes' nature reserve with bogs and peat land where moor plants such as bog myrtle (Myrica gale) and cloudberry (Rubus chamaemorus) are protected. It is one of the largest natural habitats for cranes in Poland. The panorama of 'Bielawskie Marshes' from can be seen from a wooden observation tower situated on the blue trail.

2. Źródliska Czarnej Wody (Blackwater Springs) are extensive area of outflows forming a small river leading to the sea - the Czarna Woda. Its upper course is deeply cut into the Żarnowiecka Upland. Nearby, we can see the glacial erratics called 'God's Foot' and 'Devil's Stone'. In order to protect the landscape and the natural assets, a forest and floral nature reserve has been established there, named after the springs. They are situated about $1 \mathrm{~km}$ north-east of the village of Świecino (Krokowa gmina, Puck powiat). The Czarna Woda flows directly into the Baltic Sea between Karwia and Jastrzębia Góra.

3. Źródło Marii (Mary’s Spring) emerges from the edge of an upland (Kaszuby Lake District), in the area of the Oliwa Forests in Gdynia (the southern part of Wielki Kack). The water flows out from a rounded opening strengthened with gravel and stone, in the middle of which (on an islet) is a small shrine where a statue of the Virgin Mary has been placed. Beside it, on a tourism trail, is a small, stone drinking fountain. 
A small stream of the same name flows out of the spring (about 1 l/s) in Kacze Łęgi ('Duck Meadows') nature reserve, and into the River Kacza, which in turn flows into Gdańsk Bay. This spring with miraculous, healing water is situated on two tourism trails (black and yellow) and on a cycling trail in the Trójmiasto Landscape Park.

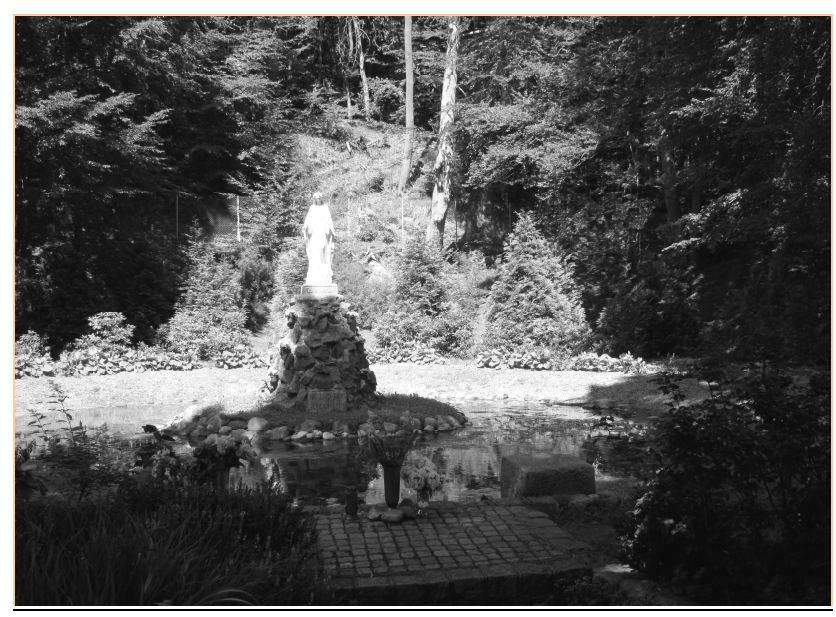

Photo 1. Rounded niche of Mary's Spring with the statue of Virgin Mary (Gdynia, 3 $3^{\text {rd }}$ August 2011)

4. Źródła Staniszewskie (Staniszewskie Springs) form the largest complex of springs and seepages in northern Poland (gmina and powiat of Kartuzy). The groundwater flows out on the steep left slope of the upper Łeba valley, starting streamlets which flow directly into this river. The springs, together with unique plant communities and rare plant species, form the 'Staniszewskie Springs' nature reserve, within the Kaszubski Landscape Park (Kaszuby Lake District). The reserve can be entered by a forest road from Mirachów (about $3 \mathrm{~km}$ ) towards Sianowo (forest district: Glinne), marked as a red PTTK (Polish Tourism and Sightseeing Society) tourism trail.

5. Źródetko Polanów (Polanów Spring) has miraculous healing 'powers', emerging on the slope of the sacred Polanowska hill (156 m above sea level), about $2 \mathrm{~km}$ south-west of Polanów, near Koszalin (Polanów gmina, Koszalin powiat). At present, it is a shallow stone well with a bucket for drawing water. It is covered and decorated with a picture of Virgin Mary. Next to it, there is a wooden bridge over the outlet of a periodic stream which flows into the River Grabowa - a left tributary of the Wieprza. Along the forest path leading to the top of the hill, there are 20 rosary stations, carved in wood. Next to the summit is a Franciscan hermitage with a Virgin Mary sanctuary - a Franciscan pilgrimage centre.

6. Ptasie Źródło (Bird Spring) is a spring with medicinal mineral water known since 1688 . It is surrounded by a circular wall of stones with a shallow basin and a drinking fountain in the centre. The spring's discharge is small $(<0.5 \mathrm{l} / \mathrm{s})$ and the water colours the stones brick-red and brownish because it contains iron compounds. The spring is situated on the right slope of the Kamienny Potok ravine, close to Borkowo sanatorium in Połczyn Zdrój (Połczyn Zdrój gmina, Świdwin powiat). The spring can be reached following the yellow Wokót Połczyna Zdroju trail which runs through the buffer zone of the Drawski Landscape Park ('Połczyńska Switzerland'). Kamienny Potok is a right tributary of the Wogra, which in turn is a left tributary of the Dębnica flowing later into the Parsęta.

7. Źródełko 'Piaseczno' (Źródełko Matki Bożej) the water in Piaseczno (Mother of God) Spring has miraculous (healing) properties. The spring is situated on the eastern slope of the valley of the Piaseczno stream which flows into the River Wierzyca - a left tributary of the Vistula. At present it is a relatively deep well with a windlass and a bucket to draw water. At the site where the miraculous spring emerged, a chapel in the shape of a boat was built, as well as 15 rosary stations. Next to the well, there is a car park for those travelling by the Tczew-Bydgoszcz road, about $0.5 \mathrm{~km}$ east of Piaseczno (Gniew gmina, Tczew powiat). Nearby, we can find the oldest Virgin Mary sanctuary in Pomorze.

8. Źródełko 'Gietrzwałd' (Gietrzwałd Spring) emerges from the foot of a hill, in a small square hollow, surrounded by rounded and flat stones. In order to reach it, a few steps must be descended. The water flows from a pipe (a drinking fountain of less than $0.5 \mathrm{l} / \mathrm{s}$ discharge), over which there are three marble bas reliefs depicting Moses touching a rock from which water is emerging, and Israelites drinking water in the desert. Next to the spring, there is a figure of the Virgin. Above, at the edge of the forest, we find 15 stations of the cross. The miraculous spring is situated near the Virgin Mary Basilica in Gietrzwałd near Olsztyn which is why it is visited by a great number of pilgrims and tourists (Gietrzwałd gmina, Olsztyn powiat). The spring starts at the foot of the Giławka valley, a tributary of the River Gilwa, which in turn is a tributary of the Pasłęka flowing into the Vistula Bay.

9. Źródła Rzeki Stążki (Stążka River Springs) are powerful underground waters forming the Stążka River, offering exceptionally spectacular views. They are considered to be a monument of nature and can be found in a nature reserve bearing the same name. The springs themselves have their own name - Wodogrzmoty Krasnoludków (Dwarfs' Waterfall), which comes from the fact that the water emerges at great speed. The springs are situated in the Tucholski Landscape Park (Tucholskie Forests), about $13 \mathrm{~km}$ north-east of 
Tuchola between Kowalskie Błota and Biała. The springs can be reached from the village of Biała, going south-east along the Szlak Partyzantów AK (Home Army Partisan Trail). The Stążka River is a left tri butary of the Brda (Cekcyn gmina, Tuchola powiat).

10. Źródła Rzeki Łyny (Łyna River Springs) are several dozen seepage springs flowing out from numerous semi-circular openings and forming a stream. The waters flow out from fluvio-glacial sand above a substratum of impermeable Miocene loam, at the foot of a terminal moraine at an altitude of $155 \mathrm{~m}$. Differences in altitude (up to $30 \mathrm{~m}$ ) of individual parts of this ravine make the local landscape very interesting. The phenomenon of headward erosion occurs here which is particularly rare in the lowlands, which is why the area is under protection and has been turned into a landscape and geomorphological nature reserve named after the springs. The springs are situated about $1.5 \mathrm{~km}$ north-east of the village of Łyna, Nidzica gmina (Mazury), on the Olsztyn-Dobrzyń green tourism trail. The River Łyna is a left tributary of the Pregola which flows into Kaliningrad Bay.

11.Źródło Worpickiego (Worpicky Spring German: Worpitzky Quelle) is a high discharge spring (1-2 l/s), with a temperature of $8^{\circ} \mathrm{C}$, flowing out from the base of an opening ( $10 \mathrm{~m}$ in diameter), at the foot of a steep scarp overgrown with beech trees. Groundwater flows out both at the foot of the slope and below it. On the northern side some concrete steps can be seen - remnants of those from 1894 which make a descent to the spring easier. The spring is situated in the Szczeciński Landscape Park called 'Primaeval Beech Forest', in the 'Beech Hills' nature reserve. The spring flows down the eastern slope of the valley of the Chojnówka stream and is its right tributary. In the area of Szczecin Zdroje, the Chojnówka flows through a covered channel into the Cegielinka, a right tributary of the Regalica. The spring can be reached by the road

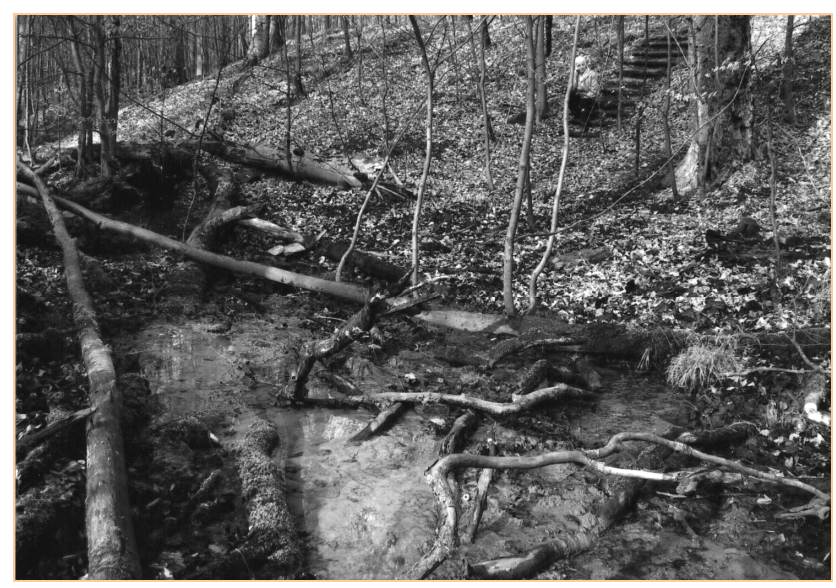

Photo 2. Worpicky Spring. The upper part of the photo shows the remnants of steps from 1894 (Bukowa Forest, 21 ${ }^{\text {st }}$ March 2012) from Szczecin-Podjuchy to Kołów. Midway, in the area of Przełęcz Trzech Braci (Three Brothers Pass) we must turn left (to the north) onto the Chojnowska road and after $1.5 \mathrm{~km}$, about $50 \mathrm{~m}$ to the east (right) of this road, we will find the spring (green and blue tourism trails).

12.Źródło Chojnówki Chojnówka Spring (also known as Oczko Luizy or Marzanny), has an elongated opening, consisting of several charming small outlets, especially on the western side, with groundwater seepages and outflows of 1-2 l/s discharge, and a temperature of $9^{\circ} \mathrm{C}$. On the northern side, there is a small, silty pond with a stone barrier, partly damaged, built in 1899. The outlets extend over $90 \mathrm{~m}$ in length and several metres in width, and it is the place where the Chojnówka stream starts ('Beech Hills'). Chojnówka Spring can also be found in the Szczeciński Landscape Park ('Beech Forest'), in the same valley as the Worpicky Spring, only a little more to the south. It is situated only $800 \mathrm{~m}$ north of the Przełęcz Trzech Braci (Three Brothers Pass).

13. Źródło 'Lwia Paszcza' (Lion's Mouth Spring) is an outflow of groundwater at the rate of about $0.5 \mathrm{l} / \mathrm{s}$ throughout the year whose water temperature is $9{ }^{\circ} \mathrm{C}$. It is also situated in the Szczeciński Landscape Park ('Beech Forest'). Until 1998, the spring was decorated by a cast iron lion's mouth made in 1893 from which a stream of water used to flow into a small rectangular basin $(1.5 \times 2.0 \mathrm{~m})$. Now, only the remains of a concrete wall are left. At present, the water flows out at a different place beneath a small scarp, with rustycoloured stones (due to iron compounds). The spring is situated on the left bank of the Lisi Potok valley and is surrounded by majestic hills - Odyniec to the north (101.2 $\mathrm{m}$ above sea level) and Zamczysko to the southeast $(103.4 \mathrm{~m})$. Next to the spring, there is a camping space with wooden benches and tables and a place to make a bonfire. Lisi Potok is a right tributary of the River Trawna, which in turn is a right tributary of the

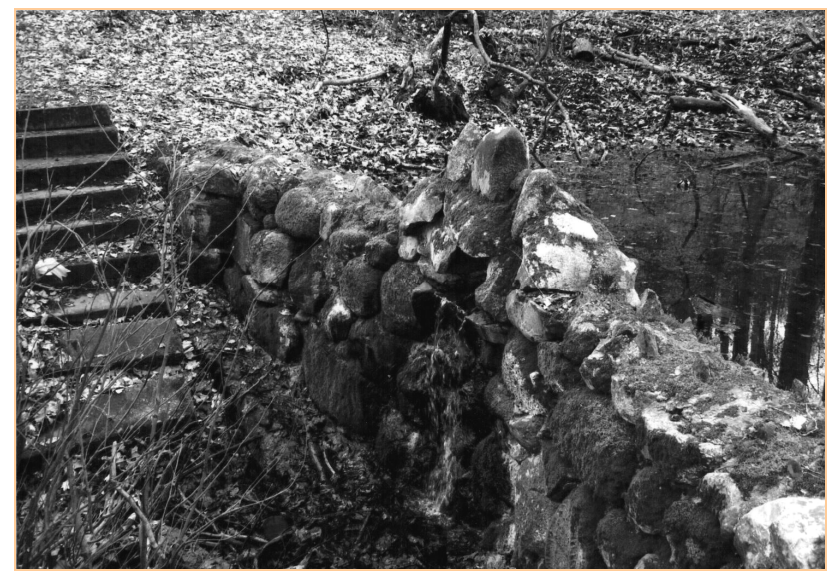

Photo 3. Stone barrier with a small waterfall, holding back the water of Ponikwa Spring (Bukowa Forest, 21 ${ }^{\text {st }}$ March 2012) 
Niedźwiedzianka, which flows into the Płonia. The spring is situated in the central part of the 'Beech Forest'. It can be reached by a road from Kolowa, called Kira, going northwards. The spring is found about $2 \mathrm{~km}$ from Kołów by a meander, very near the left bank of Lisi Potok.

14. Źródło Ponikwy (Ponikwa Spring) also known as Oczko Ponikwy, is in the form of seepages and outflows. It starts at the foot of a scarp through an opening $(20 \times 30 \mathrm{~m})$, surrounded by slopes, which are up to $4 \mathrm{~m}$ deep in its northern part. From the south, the opening is closed off by a stone barrier built in the early $20^{\text {th }} \mathrm{c}$., holding back the water and forming a small waterfall of about $0.5 \mathrm{l} / \mathrm{s}$ discharge and a temperature of $10{ }^{\circ} \mathrm{C}$. The opening is situated in a broad valley, in an area of considerable variation in height, as much as $50 \mathrm{~m}$ between Wodnik Hill (130.5 $\mathrm{m}$ above sea level) in the west and Łowczyn $(137.7 \mathrm{~m})$ in the north east ('Beech Forest'). The spring, which is the main source of the Ponikwa stream, gives off a smell of methane. The name of this stream refers to the fact that after flowing for several hundred metres, opposite Czajcza $(127 \mathrm{~m})$ the stream dis-appears into a permeable substratum. The spring is situated at the exit of the Świstówka valley, in the central part of the 'Beech Forest' (Szczeciński Landscape Park). It can be reached by the road mentioned above, leading from Szczecin-Podjuchy to Kołów. Midway, in the area of the Przełecz Trzech Braci (Three Brothers Pass) we must turn right (southwards) and after going $1 \mathrm{~km}$ along the blue trail, we find the spring.

15. Źródło Świętego Rocha (St Roch Spring) starts under the edge of a morainic hill named after the same saint. The water flowing from beneath the scarp forms a stream, visibly cutting into the valley side. St Roch Hill, which had been the site of a Slavonic cult, offers a beautiful view to the Vistula valley. The John Paul II educational path runs across the hill and by the spring. Due to its landscape assets, the spring is a monument of nature and is situated in Topolno on the left side of the lower Vistula valley (Pruszcz gmina, Świecie powiat).

16. Źródełko 'Górka Klasztorna' (Górka Klasztorna Spring) is currently a well with two hand pumps for drawing water in a village of the same name. The spring became famous in 1079, when a shepherd seeking to graze some cattle noticed a figure of the Virgin Mary on an enormous oak tree. After this revelation, the water in the nearby spring acquired miraculous (healing) properties. The oldest Virgin Mary Sanctuary in Poland was erected there, with the revered icon of the Virgin Mary Górecka. Nearby, we can find a Pilgrim centre. The village of Górka Klasztorna lies near Łobżenica (a gmina), in Piła powiat (Krajeńskie Lake District). The spring is situated in the catchment area of the stream flowing from Kruszki - a left tributary of the River Łobżanka, which in turn is a right tributary of the Noteć.

17. Leśne Źródła (Forest Springs) are formed by abundant seepage of groundwater flowing in the form of a thin sheet over a fluvial terrace on the south bank of Tuczno Lake. The terrace extends slightly above the lake surface, at the foot of a steep slope. The water flows throughout the year, preventing the area becoming overgrown. The groundwater has stable temperature of about $7^{\circ} \mathrm{C}$, therefore we can see green stretches of spring moss and star duckweed even in winter. Due to its natural assets, the area is a nature reserve protecting numerous springs and the fluvial terrace which are part of a natural forest ecosystem. The spring is situated about $1.5 \mathrm{~km}$ south-west of Tuczno. Tuczno Lake is situated in the gmina of Tuczno, Wałcz powiat, on the Drawska Plain of the Wałeckie Lake District. Tuczno Lake is crossed by the River Rudnica - a left tributary of the Płociczna, which in turn is a left tributary of the Drawa.

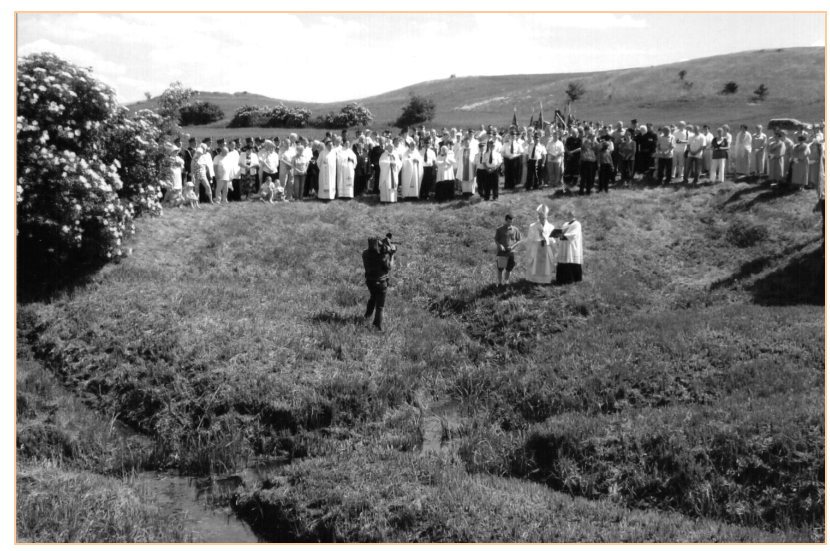

Photo 4. Otto's Spring niche. At the background - consecration of the water by the metropolitan Bishop of Szczecin-Kamien (Brzesko, $4^{\text {th }}$ June 2011)

18. Źródełko Ottona (also Studnia Świętego Ottona and Źródto Świętego Ottona) Otto's Spring starts from a rectangular opening $(30 \times 35 \mathrm{~m})$ and about $2.5 \mathrm{~m}$ deep. The area in front is cut with 9 ditches draining water at $1 \mathrm{l} / \mathrm{s}$, temperature $10{ }^{\circ} \mathrm{C}$. The ditches form a linear outflow towards the north, the beginning of the Jordan stream. Beside the stream, by an unsurfaced road, there is a cross with a plaque commemorating the baptism of the inhabitants of Brzesko on $3^{\text {rd }}$ June 1124. The spring has become increasingly well-known and popular among pilgrims and tourists due to the annual consecration of its water since 2010 by the metropolitan Bishop of Szczecin-Kamien. The spring is situated on the northern edge of the Myśliborskie Lake District (including the Pyrzycka lowlands) about $0.5 \mathrm{~km}$ east of the village of Brzesko, in the gmina of Pyrzyce. The line of longitude of $15^{\circ}$ East, marking the beginning of Central European time zone, 
runs nearby. The Jordan stream joins a system of water-courses and ditches (Stróżewski) which enter the River Płonia from the left.

We should mention St Otto's Well here (also known as St Otto's Spring), situated in a park in the eastern part of Pyrzyce (the southern edge of the Pyrzycka lowlands). It is a shallow well (about $3 \mathrm{~m}$ deep), covered with a rectangular steel frame $(1.2 \mathrm{x}$ $3.5 \mathrm{~m})$. The whole, including a polished grey-pink granite cross, forms a unique monument in stone (flags and blocks). It is surrounded by a low stone wall. The site commemorates the baptism of Pyrzyce inhabitants in July 1124 . There used to be a spring here which started a stream flowing into the River Płonia.

19. Źródełko w Przelewicach also known as 'Źródlisko'. A spring in Przelewice gmina, Pyrzyce powiat, flows from a 4 metre-wide opening, at the foot of a 4-5 $\mathrm{m}$ high scarp. Groundwater flows out in a semicircle from the scarp, forming a charming pond with boulders of about one metre in diameter. It is rusty red due to iron compounds, about $1 \mathrm{l} / \mathrm{s}$ discharge and a temperature of $10{ }^{\circ} \mathrm{C}$. It flows as a narrow trickle into the stream flowing next to it ('Przelewiczanka'), which enters Lake Płon from the south. Lake Płon is traversed by the River Płonia, which flows into Lake Dąbie. The spring is situated in the arboretum in Przelewice, the 'Avenue of Springs' on the western slope of the valley of the 'Przelewiczanka' stream (northern edge of the Myśliborskie Lake District upland). There are 20 more outflows along the 'Avenue of Springs' which flow into 'Przelewiczanka', and with a unique flora (e.g. wild lettuce).

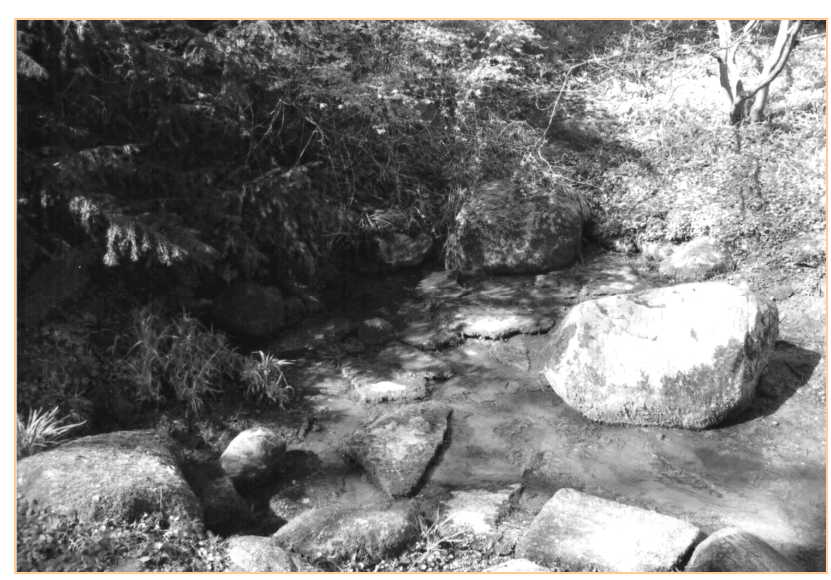

Photo 5. The small "Źródliska" niche with boulders in the Dendrological Garden in Przelewice (9th April 2012)

20. Źródło 'Boży Dar' (God's Gift) is a quite wide, flat, marshy area of seepages and outflows of groundwater, at the foot of a terminal moraine. It is situated in a forest, the source of the Lodowy Strumien flowing into Barlineckie Lake. The water (1-2 l/s) is very cold in summer, which has given its name to the stream. In many places on the stream bed there are rusty traces of iron compounds. The spring, which is a monument of nature, is situated near the village of Mroczkowo, south of the gmina of Barlinek, Myślibórz powiat, on the south bank of Barlineckie Lake (in BarlineckoGorzowski Landscape Park). It is a varied, post-glacial landscape with considerable variations in height up to $40 \mathrm{~m}$ above the lake surface. The spring lies on the green tourism trail running around Barlineckie Lake, including an Ecological Educational Path. The spring is about $4 \mathrm{~km}$ to the south-west of Barlinek. Barlineckie Lake is a source of the River Płonia, which flows into Dąbie Lake.

21. Źródło Świętego Huberta (St Hubertus Spring) is a walled and covered spring of about $8 \mathrm{l} / \mathrm{min}$. discharge built of variously coloured stone, about $3 \mathrm{~m}$ high (Kamienny Dom). The water flows out as a rusty trickle (iron compounds), joining a nearby lake. The spring is $5 \mathrm{~m}$ from Lake Ostrowieckie on its steep eastern bank, near the village of Wiktorowo (Gąsawa gmina, Żnin powiat), about $10 \mathrm{~km}$ south-east of Żnin (Gnieźnieńskie Lake District). The spring can be reached by walking from Wiktorowo holiday centre alongside the lake, and down a forest path. The spring is situated right opposite Zabłoccy Bay. Due to its landscape, the spring is considered a monument of nature. Lake Ostrowieckie is linked to the River Noteć via the Foluska stream (a left tributary).

22. Źródła Gąsawki (Gąsawka Springs) emerge from the bottom of Lake Głęboczek Wielki, situated in a forest, $109 \mathrm{~m}$ above sea level. They are also formed by nearby outlets at the foot of the lake's banks. In order to protect the valuable natural assets of the area, a nature-landscape reserve has been established there with the same name. It protects seepage outlets and their unique flora, as well as a Nature-Forest Path with many information boards on the hydrography, flora and fauna of the Gąsawka valley. The springs are situated close to Głęboczek near Niestronna, (Gąsawa gmina in the south-eastern part of Żnin powiat Gnieźnieńskie Lake District). The Gąsawka River is a left tributary of the Noteć, which in turn is a right tributary of the Warta.

23. Źródełko 'Grabarka' (Grabarka Spring) is a miraculous spring with a colourful shrine and a well with a pump. Next to the shrine is the Kryniczka stream which makes it easy for pilgrims to drink and wash themselves in the healing water. The spring starts at the foot of a sacred hill Święta Góra in the village of Grabarka (Nurzec-Stacja gmina, Siemiatycze powiat Drohicka Uplands). On the top is an Orthodox sanctuary with a church, monastery, two pilgrim centres and over 10,000 crosses. The Kryniczka stream flows into the River Moszczona, a right tributary of the Bug. Grabarka Spring is situated about $8 \mathrm{~km}$ east of Siemiatycze. 
24. Licheńskie Źródetko (Licheń Spring) is currently a well, hidden inside a brick chapel. Next to it, near another chapel, there are five taps to draw water, and a little concrete pool for hand washing. After numerous cases of recovery from drinking this water, the spring is now believed to have miraculous powers. It is situated beneath St Dorota Church, on the east bank of Lake Licheńskie in the village of Stary Lichen (Ślesin gmina, Konin powiat - Kujawskie Lake District). Next to it, there is one of the largest Virgin Mary sanctuaries in Poland, with the Virgin Mary Basilica, a Way of the Cross, Golgotha, numerous monuments, commemorative boulders, etc, as well as a well-developed infrastructure catering for the needs of pilgrims and tourists. Lake Licheńskie is connected to the River Noteć via the Warta-Gopło Canal.

25. Źródła Ciosenki (Ciosenka Springs) are situated close to one another and are one of the most interesting and largest in central Poland. They flow from two outlets, with up to $45 \mathrm{l} / \mathrm{s}$ discharge, forming the Ciosenka stream. The springs are situated on the northern edge of the village of Rosanów, north of Zgierz (gmina and powiat). About $1 \mathrm{~km}$ from the springs is a working water mill (with a water wheel). Near the springs, about $0.5 \mathrm{~km}$ north of Rosanów, is the 'Ciosny' nature reserve protecting a natural site of exceptionally impressive junipers, growing on the central former dune area of the Łódź Hills. The Ciosenka stream is a right tributary of the River Dzierżązna, flowing into the Czarnawka, which in turn flows into the Moszczenica - a left tributary of the Bzura.

26. Źródło Królewskie (Royal Spring) consists of natural springs with a high discharge of groundwater, at the edge of a flood plain near the River Zagożdżonka (a left tributary of the Vistula). The site includes wooden bridges for tourists and the main spring is surrounded by a sandstone wall. In order to protect these springs, as well as the varied landscape around with its marshes, mixed forests and rare flora, a nature reserve has been established under the same name. There is an educational path, a picnic area (covered) and a bonfire site. The spring has very clean, cold and refreshing water, appreciated by visitors. The water was once drunk by King Władysław Jagiello, and the spring was named after him. It is situated in Kozienicka Forest (Kozienicki Landscape Park), on the Radom-Kozienice route near Augustów, (Pionki gmina, Radom powiat - Kozienice Lowland). To reach the spring, turn right $1.2 \mathrm{~km}$ east of Augustów, into a fire break (used as a parking space) and travel a further $3.2 \mathrm{~km}$ along a forest road (to another parking space).

27. Niebieskie Źródła (Blue Springs). Three karst springs separated one from another by islets. Each consists of a number of smaller springs at the bottom of two 'basins' up to $4.5 \mathrm{~m}$ deep. The emerging water (about $9^{\circ} \mathrm{C}$ ) brings out unique blue and green shades on its sandy base, depending on the weather conditions and the position of the sun. The main aquifer lies in jointed Jurassic limestone and the springs' discharge reaches about $80 \mathrm{l} / \mathrm{s}$ being the source of the River Jana flowing into the Pilica. They are in the Pilica valley, on its right bank, in the south-eastern part of Tomaszów Mazowiecki (Modrzewski road). A nature reserve has been established there, under the same name in order to protect these unique colourful springs and the surrounding landscape.

Key observations and conclusions:

1. The springs of the Polish Lowlands are mainly 'layer' and descending springs, flowing from Quaternary sand and gravel formations. Only Niebieskie Źródta are joined by water coming from Mesozoic limestone formations.

2. The distribution of touristically-attractive springs in the Polish Lowlands is uneven. The majority can be found in areas with more varied relief, mainly areas of end moraines and moraines which are deeply cut into by river valleys and ribbon lakes. Springs are rarest in areas with poorly developed relief.

3. Among the 27 springs presented, 17 are legally protected (8 nature reserves, 5 landscape parks, 4 monuments of nature), 7 are related to religious pilgrimages, and the remaining three are situated close to nature reserves and one is in an arboretum.

4. The phenomenon of a spring flowing out from under the ground is associated with crystal clear water, a bubbling sound and mystery. A spring is usually surrounded by lush greenery. Moreover, it is the beginning of a watercourse, situated in an area of varied relief and interesting geological structure. These assets, as well as other advantages both natural and human make them attractive tourism sites.

5. The most popular springs, visited especially on indulgence days, are small ones next to Virgin Mary sanctuaries. Pilgrims and tourists believe they have miraculous (healing) powers. Their water is both drunk and used for washing those parts of the body considered to be sick.

6. Many springs which were popular in the past, especially those associated with religious cults, have drastically decreased in discharge or completely disappeared. Some centuries ago, they flowed onto the surface, today the water can only be drawn from wells.

7. The majority of the springs presented in the article have been taken under special protection due to their valuable hydrological, geomorphological and medicinal properties or other natural assets. They are usually situated in national parks, landscape parks, or nature reserves, and have often become monuments of nature. 
In general, the aim of the article has been achieved, although it was not possible to find information regarding the discharge and temperature of water in each case. We should remember, however, that the springs described above are mostly 'layer' springs, flowing out from relatively shallow postglacial formations, so to some extent their discharge and temperature will depend on the season.

\section{BIBLIOGRAPHY}

AlEXANDROWICZ Z., DRZAŁ M., KOZŁOWSKI S., 1975, Katalog rezerwatów i pomników przyrody nieożywionej w Polsce, Studia Naturae 26.

BAJKIEWICZ-GRABOWSKA E., MIKULSKI Z., 2006, Hydrologia ogól$n a$, Wyd. Naukowe PWN, Warszawa.

BAŚCIK M., URBAN J., 2007, Konserwatorska ochrona źródeł w Polsce, [in:] Źródta Polski - wybrane problemy krenologiczne, P. Jokiel, P. Moniewski, M. Ziułkiewicz (eds.), Uniwersytet Łódzki, Łódź.

CHEŁMICKI W., JOKIEL P., MichalCZYK Z., MONIEWSKI P., 2010, Rozmieszczenie i wydajność źródeł w Polsce, [in:] Hydrologia $w$ ochronie $i$ kształtowaniu środowiska, A. Magnuszewski (ed.), Monografie Komitetu Inżynierii Środowiska PAN, 69, 2.

CHOIŃSKI A., KANIECKI A., 1996, Wody Ziemi, Wyd. Kurpisz, Poznań.

DOMIAN G., KuPIEC M., 2010, Źródła, [in:] Księga Puszczy Bukowej, G. Domian, K. Ziarnek (eds.), Wyd. Regionalna Dyrekcja Ochrony Środowiska, Szczecin.

DYNOWSKA I., 1986, Regionalne zróżnicowanie źródeł w Polsce, Folia Geographica, 18, Ser. Geographica Physica, Kraków.

DYNOWSKA I., TLAŁKA A., 1982, Hydrografia, Wyd. Naukowe PWN, Warszawa.

FORYSIAK J., MONIEWSKI P., 2006, „Piękne Źródło” w Imielniku, [in:] Źródta - środowiskowe aspekty badań, P. Moniewski, P. Tomalski, M. Ziułkiewicz (eds.), Uniwersytet Łódzki, Łódź.

GŁĄBIŃSKI Z. (ed.), 2009, Tajemnice krajobrazów Pomorza Zachodniego, Forum Turystyki Regionów, Szczecin.
JACKOWSKI A. (ed.), 1998, Miejsca święte Rzeczypospolitej, Wyd. Znak, Kraków.

JOKIEL P., MONIEWSKI P., ZIUŁKIEWICZ M. (ed.), 2007, Źródta Polski - wybrane problemy krenologiczne, Uniwersytet Łódzki, Łódź.

KONDRACKI J., 2009, Geografia regionalna Polski, Wyd. Naukowe PWN, Warszawa.

KRYGIER M. (ed.), 2007, Turystyczna encyklopedia Polski, Wyd. Pascal, Bielsko-Biała.

KWIATEK J., LIJEWSKI T., 1993, Polska. Podręczny leksykon geograficzny, "Troja”, Torun.

LIJEWSKI T., MIKUŁOWSKI B., WYRZYKOWSKI J., 2008, Geografia turystyki Polski, PWE, Warszawa.

ŁĘCKI W., 2005, Kanon krajoznawczy Polski, Wyd. PTTK „Kraj”, Warszawa.

MAIK W. (ed.), 2000, Polska I, Wyd. Kurpisz, Poznań.

MAKSYMIUK Z., MELA S., 1995, Źródła Polski Środkowej, Acta Universitatis Lodziensis. Folia Geographica, 20.

MARCINEK K., ChruŚCICKI D., 1976, Przewodnik po Polsce, Wyd. Sport i Turystyka, Warszawa.

MIKULSKI Z., 1965, Zarys hydrografii Polski, Wyd. Naukowe PWN, Warszawa.

MiLEWSKA M.I. (ed.), 1998, Stownik geograficzno-krajoznawczy Polski, Wyd. Naukowe PWN, Warszawa.

MONIEWSKI P., 2004, Źródta okolic Łodzi, Łódzkie Towarzystwo Naukowe, Łódź.

MONIEWSKI P., TOMALSKI P., ZIUŁKIEWICZ M. (eds.), 2006, Źródta - środowiskowe aspekty badań, t. I, Uniwersytet Łódzki, Łódź.

OlACZEK R., 2008, Skarby przyrody i krajobrazu Polski, Multico Oficyna Wydawnicza, Warszawa.

PASIECZNY R., BAJCAR A., OMILANOWSKA M., 2008, Atrakcje turystyczne Polski, Multico Oficyna Wydawnicza, Warszawa.

POLESZCZUK G., ZAMOSNA J., ZiARNEK K., 1997, Monitoring wód źródliskowych w Szczecińskim Parku Krajobrazowym, Przegląd Przyrodniczy, 9 (1-2).

STARKEL L. (ed.), 1999, Geografia Polski - środowisko przyrodnicze, Wyd. Naukowe PWN, Warszawa.

WIŚNIEWSKI W., 1998, Lecznicze źródetka w miejscach sakralnych, Instytut Teologiczny Księży Marianów, Kraków.

ŻELAWSKI J., 2010, Odwiedzit Brzesko, Instytut Teologiczny Księży Marianów, Kraków. 